\title{
IMPLEMENTASI PROGRAM “LESS WASTE EVENT” PADA PELAKSANAAN INDONESIA OUTDOOR FESTIVAL 2020 OLEH CONSINA OUTDOOR SERVICES EVENT DI JAKARTA CONVENTION CENTER
}

\section{[Implementation Of "Less Waste Event" Program In The Indonesia Outdoor Festival 2020 By Consina Outdoor Services Event In Jakarta Convention Center]}

\author{
Pradenja Ayuningtiyas ${ }^{1)}$, Anisatul Auliya ${ }^{2)}$ \\ 1)Program Pendidikan Vokasi, Universitas Indonesia \\ 2) Program Pendidikan Vokasi, Universitas Indonesia
}

Diterima 06 Oktober 2020 / Disetujui 27 November 2020

\begin{abstract}
The "Less Waste Event" program began to attract the attention of organizers and was applied to MICE activities. The purpose of implementing this program is to anticipate excessive waste production and to be responsible for environmental sustainability. Indonesia Outdoor Festival 2020 event which was held by the Consina Outdoor Services Event at the Balai Sidang Jakarta Convention Center also made the "Less Waste Event" Program a concern. This study aims to find out how the implementation of the "Less Waste Event" Program and determine the factors that influence the successful implementation of the "Less Waste Event" Program at the event. This research is a descriptive research with a case study approach with research object implementation of the "Less Waste Event" program in the implementation of the Indonesia Outdoor Festival 2020 by the Consina Outdoor Services Event at the Balai Sidang Jakarta Convention Center held on March 12 15, 2020. Data collection methods used in this research are observation, interview, and literature study. Data analysis method used is qualitative descriptive analysis. The implementation of the "Less Waste Event" program at the event has been going well because all methods of implementation, namely before, during and after the event have been carried out in accordance with the guidelines. Based on the predetermined assessment criteria the program's implementation was considered successful.
\end{abstract}

Keywords: MICE Industry, Less Waste Event Program, Event Organizer

\begin{abstract}
ABSTRAK
A Program "Less Waste Event" mulai menjadi perhatian penyelenggara dan diaplikasikan pada kegiatan MICE. Tujuan dari penerapan program ini adalah mengantisipasi adanya produksi sampah yang berlebih serta bertanggung jawab atas keberlangsungan lingkungan. Acara Indonesia Outdoor Festival 2020 yang digelar oleh Consina Outdoor Services Event di Balai Sidang Jakarta Convention Center juga menjadikan Program "Less Waste Event" perhatian. Penelitian ini bertujuan untuk mengetahui bagaimana implementasi Program "Less Waste Event" dan mengetahui faktor-faktor yang mempengaruhi kesuksesan implementasi Program "Less Waste Event" pada acara tersebut. Penelitian ini merupakan penelitian descriptive research dengan pendekatan case study dengan objek penelitian implementasi Program "Less Waste Event" pada pelaksanaan Indonesia Outdoor Festival 2020 oleh Consina Outdoor Services Event di Balai Sidang Jakarta Convention Center yang diselenggarakan pada 12 - 15 Maret 2020. Metode pengumpulan data yang digunakan dalam penelitian ini adalah observasi, wawancara, dan studi pustaka. Metode analisis data yang digunakan adalah analisis deskriptif kualitatif. Implementasi Program "Less Waste Event" pada acara tersebut telah berjalan dengan baik karena seluruh metode pelaksanaan yaitu sebelum, saat, dan sesudah pelaksanaan acara telah dilaksanakan sesuai dengan pedoman. Berdasarkan kriteria penilaian yang telah ditentukan implementasi program dinilai sukses.
\end{abstract}

Kata Kunci: Industri MICE, Program “Less Waste Event”, Pengelola Acara. 


\section{Latar Belakang}

\section{PENDAHULUAN}

Industri MICE yang di dalamnya terdapat bidang meeting, incentive, conference, dan exhibition menjadi salah satu sektor unggulan pariwisata di Indonesia. Indonesia sebagai negara destinasi tujuan wisata turut diperhitungkan oleh pasar wisata MICE. Hal itu dapat dilihat dari kepercayaan yang diberikan untuk menjadikan Indonesia tuan rumah untuk pelaksanaan event internasional seperti Asian Games 2018, Asian Para Games 2018, hingga rapat tahunan IMF-Bank Indonesia 2018.

$$
\text { MICE juga menunjukkan }
$$

kontribusinya terhadap pengembangan pariwisata dalam arena komersial. MICE merupakan daya tarik tujuan, tetapi lebih mendasar, merupakan proposisi pemasaran utama dalam mempromosikan destinasi wisata mengingat semakin meningkatnya daya saing global dengan tujuan menarik pengeluaran pengunjung. (Donald Getz, 2016: 593) Dengan begitu, menjadi penting untuk terus dilakukan pengembangan terhadap industri MICE.

Pada acara Indonesia Business Event Forum (IBEF) 2019 yang digelar di Balai Sidang Jakarta Convention Center, Direktur Industri Pariwisata dan Ekonomi Kreatif, Teguh Sambodo, menyatakan bahwa MICE ditempatkan sebagai sektor unggulan untuk pendapatan devisa negara hingga tahun 2024. Pertimbangan menjadikan MICE sebagai sektor unggulan didasari oleh besarnya dampak dari kegiatan MICE. Banyak dampak positif yang tercipta dari kegiatan MICE bagi perekonomian seperti pendapatan, penyerapan tenaga kerja, hingga pendapatan dari bisnis pariwisata lainnya. Jika merinci data dari Oxford Economics 2018, dampak ekonomi dari rata-rata kegiatan MICE di tahun 2018 mencakup total pengeluaran langsung sebesar USD 6,3 milliar, rata-rata pengeluaran per peserta USD 296, jumlah partisipan 21,4 juta orang, dan membuka lapangan kerja bagi 104.000 orang. Namun,

\footnotetext{
*Korenspondensi Penulis

Email : anisatul.auliya@ui.ac.id
}

selain dampak positif, industri MICE yang terus berkembang begitu cepat juga berpotensi memberi dampak negatif.

Salah satu dampak negatif dari kegiatan MICE yaitu potensi ancaman terhadap kualitas lingkungan pada lokasi kegiatan MICE itu sendiri.

Ancaman terhadap kualitas lingkungan yang timbul dari kegiatan MICE salah satunya adalah produksi sampah. Jumlah orang yang terlibat dan sumber daya yang digunakan dalam suatu kegiatan MICE menyebabkan jumlah produksi sampah relatif banyak dengan jenis yang beragam. Tentunya jika tidak ditangani dengan baik hal ini dapat menimbulkan resiko berkelanjutan. Untuk itu dirasa perlu mengaplikasikan prinsip sustainability dalam pelaksanaan kegiatan MICE.

Sesuai dengan Undang-Undang Pengelolaan Sampah Nomor 18 Tahun 2008, bahwa setiap orang wajib mengurangi dan menangani sampah dengan cara yang berwawasan lingkungan, maka pelaksana kegiatan MICE juga turut bertanggung jawab terhadap pengelolaan sampah yang dihasilkan selama pelaksanaan kegiatannya. Mengadaptasi tiga prinsip dasar sustainable development yaitu environment responsibilities, economic responsibilities, dan social responsibilities tercipta sebuah konsep sustainable event management. (Diadopsi dari The Triple Bottom Line Approach, Green Meeting Industry Council dalam United Nations Office at Nairobi and United Nations Environment Programme, 2012: 2) Kementerian Lingkungan Hidup dan Kehutanan Republik Indonesia mengeluarkan Pedoman Pengelolaan Sampah dalam Penyelenggaraan Acara atau Pedoman Penyelenggaraan Bersih Sampah (Less Waste Event) pada tahun 2016 yang ditujukan untuk pelaku penyelenggara acara (event organizer) dan pemilik/pengelola gedung pertunjukan (venue owner/management) dalam pengelolaan sampah pada setiap penyelenggaraan, baik sebelum, selama, dan berlangsung dengan menerapkan prinsip $3 \mathrm{R}$ (reduce, reuse, dan recycle). Program "Less Waste Event" mulai menjadi perhatian 
penyelenggara dan diaplikasikan pada kegiatan MICE.

Indonesia Outdoor Festival sebagai pameran outdoor dan petualangan terbesar di Indonesia yang diadakan di Jakarta dan Surabaya telah telah berhasil menarik perhatian publik dan dikunjungi 68.000 orang pada tahun 2019. Pada tahun ke-6 pelaksanaanya, Indonesia Outdoor Festival 2020 yang akan kembali digelar di Balai Sidang Jakarta Convention Center mengusung tema "Indonesia The Greatest Outdoors". Indonesia Outdoor Festival 2020 juga turut mengaplikasikan Program "Less Waste Event" sesuai pedoman dari Kementerian Lingkungan Hidup dan Kehutanan Republik Indonesia. Tujuannya untuk mengantisipasi adanya produksi sampah yang berlebih serta bertanggung jawab atas keberlangsungan lingkungan.

Berdasarkan ketertarikan penulis saat melakukan pengamatan di lapangan pada saat acara ini berlangsung maka penulis ingin mengkaji tentang "Implementasi Program "Less Waste Event" pada pelaksanaan Indonesia Outdoor Festival 2020 oleh Consina Outdoor Services Event di Jakarta Convention Center".

\section{Identifikasi Masalah}

Berdasarkan latar belakang masalah di atas, peneliti akan melakukan identifikasi masalah, meliputi :

1. Indonesia sering kali menjadi tuan rumah untuk pelaksanaan event internasional dan kegiatan MICE ditempatkan sebagai sektor unggulan untuk pendapatan devisa negara hingga tahun 2024;

2. Ancaman terhadap kualitas lingkungan yang timbul dari kegiatan MICE salah satunya adalah produksi sampah;

3. Jumlah orang yang terlibat dan sumber daya yang digunakan dalam suatu kegiatan MICE menyebabkan jumlah produksi sampah relatif banyak dengan jenis yang beragam;

4. Pentingnya penerapan pengelolaan sampah pada setiap penyelenggaraan, baik sebelum, selama, dan sesudah acara berlangsung dengan menerapkan prinsip 3R (reduce, reuse, dan recycle). Program "Less Waste Event" mulai menjadi perhatian penyelenggara dan diaplikasikan pada kegiatan MICE.

\section{Tujuan dan Manfaat Penelitian}

Tujuan Penelitian

1. Mengetahui Implementasi Program "Less Waste Event" pada Pelaksanaan Indonesia Outdoor Festival 2020 oleh Consina Outdoor Services Event di Jakarta Convention Center.

2. Mengetahui Faktor-Faktor Apa Saja yang Mempengaruhi Kesuksesan Implementasi Program "Less Waste Event" pada Pelaksanaan Indonesia Outdoor Festival 2020 oleh Consina Outdoor Services Event di Jakarta Convention Center.

\section{Manfaat Penelitian}

1. Mengetahui penerpan pelaksanaan program "Less Waste Event" pada suatu kegiatan, yang sesuai berdasarkan pedoman dari Kementerian Lingkungan Hidup dan Kehutanan Republik Indonesia.

2. Mengetahui pentingnya penerapan Program "Less Waste Event" pada saat penyelenggaraan suatu kegiatan.

\section{Penyelenggaraan Acara (Event)}

Event merupakan kegiatan yang diselenggarakan untuk memperingati hal-hal penting, baik secara individu atau kelompok yang diselenggarakan untuk tujuan tertentu serta melibatkan lingkungan masyarakat yang diselenggarakan pada waktu tertentu. (Noor, 2013: 8).

Setiap penyelenggaraan event harus memiliki ciri tersendiri. Terdapat lima karakteristik penyelenggaraan event menurut Noor (2013: 14), yaitu:

a. Keunikan, kunci suksesnya sebuah event adalah pengembangan ide. Setiap event harus memiliki sesuatu yang berbeda dengan event lain. Event yang pernah diselenggarakan pastinya masih dapat diulangi pada kesempatan lain, misalnya event yang biasa diselenggarakan secara reguler. Tetapi, keunikan harus tetap muncul pada setiap penyelenggaraan event meskipun memiliki tema yang sama.

b. Perishability / Mudah Rusak, setiap event yang diselenggarakan tidak akan pernah sama. Dua event yang sama 
diselenggarakan pada waktu dan tempat yang sama pastinya tidak akan menghasilkan event yang sama pula. Perishability berhubungan dengan penggunaan fasilitas untuk penyelenggaraan event.

c. Intangibility / Tidak dapat Dipahami, setelah menghadiri event, yang tertinggal di benak pengunjung adalah pengalaman yang mereka dapatkan dari penyelenggaraan event. Hal ini merupakan tantangan untuk merubah bentuk pelayanan intangibility menjadi sesuatu yang berwujud, sehingga sekecil apapun wujud yang digunakan dalam event mampu mengubah persepsi pengunjung.

d. Suasana dan Pelayanan, event yang dilangsungkan di saat suasana yang tepat akan menghasilkan sukses besar, tetapi sebaliknya kegagalan event dihasilkan karena suasana yang tidak tepat.

e. Interaksi Personal, interaksi personal dari pengunjung merupakan kunci sukses penyelenggaraan event.

\section{Pengelolaan Sampah Pada \\ Penyelenggaraan Acara} Undang-Undang

Pengelolaan

Sampah Nomor 18 Tahun 2008 mendefinisikan sampah sebagai sisa kegiatan sehari-hari manusia dan/atau dari proses alam yang berbentuk padat. Selanjutnya sampah juga didefinisikan sebagai barang yang dianggap sudah tidak terpakai dan dibuang oleh pemilik/pemakai sebelumnya, tetapi bagi sebagian orang masih bisa digunakan jika dikelola dengan prosedur yang benar. (Nugroho, 2013: 23).

Berdasarkan beberapa pengertian di atas, dapat ditarik kesimpulan bahwa sampah adalah sisa kegiatan sehari-hari manusia dan/atau proses alam yang berbentuk padat yang tidak digunakan lagi, namun jika dikelola dengan prosedur yang benar masih dapat digunakan.

Praktik pengelolaan sampah dilaksanakan berbeda-beda antara negara maju dan negara berkembang, berbeda pula antara daerah perkotaan dengan daerah pedesaan, begitu pula dengan daerah perumahan dengan daerah industri. Pengelolaan sampah yang tidak berbahaya dari daerah pemukiman dan institusi di area metropolitan biasanya menjadi tanggung jawab pemerintah daerah, sedangkan untuk sampah dari area komersial dan industri biasanya ditangani oleh perusahaan pengolah sampah (Kariyawan, 2015: 318).

Dapat ditarik kesimpulan bahwa pengelolaan sampah merupakan suatu proses pengelolaan material sampah menggunakan metode khusus dengan tujuan memulihkan sumber daya alam.

\section{Program “Less Waste Event"}

Kementerian Lingkungan Hidup dan Kehutanan Republik Indonesia pada tahun 2016 mengeluarkan Pedoman Pengelolaan Sampah dalam Penyelenggaraan Acara atau Pedoman Penyelenggaraan Bersih Sampah (Less Waste Event) yang ditujukan untuk pelaku penyelenggara acara (event organizer) dan pemilik/pengelola gedung pertunjukan (venue owner/management) dalam pengelolaan sampah pada setiap penyelenggaraan, baik sebelum, selama, dan sesudah acara berlangsung dengan menerapkan prinsip 3R (reduce, reuse, dan recycle).

Tujuannya untuk memberikan pedoman kepada penyelenggara acara dalam mengelola dan mengurangi sampah pada suatu acara, mengedukasi masyarakat untuk mulai melakukan pemilahan sampah, mencegah sampah menyemari lingkungan di sekitar tempat penyelenggaraan acara, dan mengurangi jumlah sampah yang dikirim ke Tempat Pemrosesan Akhir (TPA).

Metode pelaksanaannya terbagi menjadi 3 tahapan, yaitu:

1. Sebelum Acara (Pre-Event)

a. Komunikasi Antar Pihak

b. Pembentukan Tim

c. Penyusunan Rancangan Pengelolaan Sampah pada Penyelenggaraan Acara

d. Site Plan

e. Promosi

f. Perencanaan Sarana dan Prasarana

g. Perencanaan dan Pengelolaan Lokasi Wadah

2. Pada Saat Acara (Event)

a. Kampanye Pengelolaan Sampah Pada Penyelenggaraan Acara

b. Promosi 
c. Pengurangan Sampah

3. Setelah Pelaksanaan Acara (Post-Event)

a. Evaluasi

b. Promosi Pasca Acara

Pedoman pelaksanaan Program "Less Waste Event" yang dikeluarkan oleh Kementerian Lingkungan Hidup dan Kehutanan Republik Indonesia menjadi panduan penulis untuk melakukan observasi pada implementasi Program "Less Waste Event" pada pelaksanaan Indonesia Outdoor Festival 2020 oleh Consina Outdoor Services Event di Balai Sidang Jakarta Convention Center.

\section{METODE PENELITIAN}

\section{Desain Penelitian}

Desain penelitian yang digunakan adalah deskriptif kualitatif dengan strategi penelitian studi kasus (case study). Penelitian ini memusatkan secara intensif pada suatu objek tertentu dan mempelajarinya sebagai sebuah kasus. Data studi kasus dapat diperoleh dari semua pihak yang bersangkutan, dengan kata lain dalam studi ini dikumpulkan dari berbagai sumber. (Nawawi, 2003).

Untuk memperoleh data yang berkaitan dengan penelitian digunakan studi yang merujuk pada hasil pengelolaan data primer dan sekunder. Data primer adalah data yang diperoleh secara langsung dari sumber asli atau pihak pertama yang diperoleh melalui metode observasi. Sedangkan data sekunder adalah data yang diperoleh dan dikelola oleh penulis dari berbagai sumber yang telah ada melalui studi kepustakaan.

\section{Teknik Pengumpulan Data}

Penulis melakukan penelitian di Balai Sidang Jakarta Convention Center yang dalam memperoleh dan mengumpulkan data yang diperlukan menggunakan teknik sebagai berikut:

1. Observasi

Observasi adalah metode pengumpulan data dengan cara turun langsung ke lapangan lalu melakukan pengamatan dan pengindraan. Penulis turun langsung ke lapangan dan mengamati objek penelitian dalam rangka mengumpulkan data.

2. Wawancara

Wawancara merupakan metode pengumpulan data yang digunakan dengan komunikasi dua arah untuk memperoleh informasi langsung dari sumbernya.

3. Studi Pustaka atau Literatur

Metode mengumpulkan data yang diambil dari literatur, internet, dan sumber ilmiah lainnya yang memiliki keterkaitan dengan penelitian.

\section{Lokasi dan Waktu Penelitian}

Penelitian ini dilaksanakan selama 4 (empat) bulan lamanya mulai dari Januari April 2020 di Balai Sidang Jakarta Convention Center, yang beralamat di Jalan Gatot Subroto No. 1, Jakarta 10270, Indonesia. Departemen tempat dilakukannya penelitian adalah Departemen Exhibition.

\section{HASIL DAN PEMBAHASAN}

Consina Outdoor Services Event selaku penyelenggara acara bersama dengan Balai Sidang Jakarta Convention Center selaku venue management bekerja sama dalam membuat pola pelaksanaan implementasi Program "Less Waste Event" pada pelaksanaan Indonesia Outdoor Festival 2020. Metode pelaksanaan program ini mengikuti Pedoman Pengelolaan Sampah pada Penyelenggaraan Acara yang dikeluarkan oleh Kementerian Lingkungan Hidup dan Kehutanan Republik Indonesia.

Metode pelaksanaan Program "Less Waste Event" terbagi menjadi tiga tahapan, yaitu:

1. Sebelum Acara (Pre-Event)

2. Pada Saat Acara (Event)

3. Setelah Pelaksanaan Acara (Post-Event)

Metode Pelaksanaan Sebelum Acara (PreEvent)

$\begin{array}{rlr}\text { Pada } & \text { tahapan ini dilakukan } \\ \text { perencanaan } & \text { pelaksanaan } & \text { pengelolaan }\end{array}$ sampah yang meliputi:

a. Komunikasi Antar Pihak

Dalam tahapan ini dilakukan komunikasi 
yang intens antara seluruh pihak yang terkait dalam pelaksanaan pengelolaan sampah. Diskusi antara pihak Consina Outdoor Services Event dan Balai Sidang Jakarta Convention Center dalam merencanakan pelaksanaan pengelolaan sampah dilakukan pada saat rapat koordinasi. Rapat koordinasi dilaksanakan dengan tujuan menyamakan perspektif tentang penerapan Program "Less Waste Event"antara pihak penyelenggara yaitu Consina Outdoor Services Event dan pihak venue yaitu Balai Sidang Jakarta Convention Center.

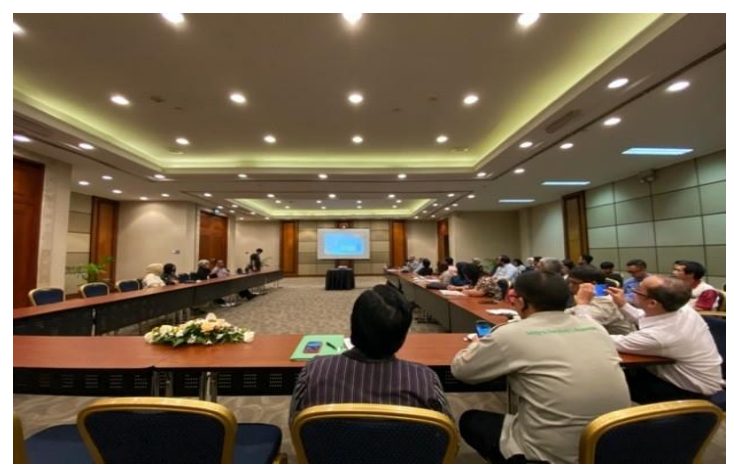

Gambar 1.

Kegiatan Rapat Koordinasi

Sumber: Dokumentasi Peneliti

b. Pembentukan Tim

Proses pembentukan tim dan pengarahan pelaksanaan Program "Less Waste Event" dilakukan pada saat technical meeting. Tim pengelolaan sampah pada penyelenggaraan acara melibatkan berbagai pihak di antaranya: penyelenggara yaitu Consina Outdoor Services Event, pengelola venue yaitu Balai Sidang Jakarta Convention Center, pembeli stand (tenant), dan pengolah sampah yaitu Departemen Housekeeping Balai Sidang Jakarta Convention Center. Tujuannya untuk mengkoordinasikan dan memastikan agar dalam penyelenggaraan Program "Less Waste Event", pengelolaan sampahnya dapat dilaksanakan dengan baik dan dikelola dengan bijak.

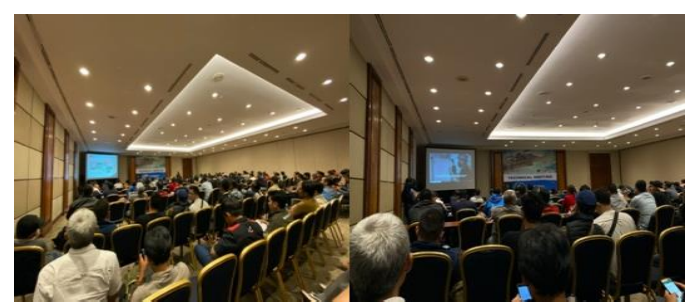

\section{Gambar 2.}

\section{Kegiatan Technical Meeting}

Sumber: Dokumentasi Peneliti

c. Penyusunan Rancangan pengelolaan Sampah pada penyelenggaraan Acara Pada tahap ini dilakukan penyusunan rancangan yang terkait dengan pengelolaan sampah meliputi antara lain penentuan tujuan dan membuat strategi untuk mencapai tujuan tersebut. Penyusunan rancangan pengelolaan sampah dilakukan oleh Consina Outdoor Services Event selaku penyelenggara acara dan diinformasikan kepada seluruh tim pengelolaan sampah. Bentuk rancangan pengelolaan sampah adalah sebagai berikut:

a) Ditentukan target untuk dapat mengajak pengunjung ikut andil dalam pengurangan sampah.

b) Strategi untuk mengelola sampah meliputi pengurangan sampah, pemilahan dari sumber sampah, pengumpulan, pengangkutan, pemilahan di TPS, dan penyaluran ke pihak pengolah sampah.

c) Mengarahkan tenant untuk menggunakan bungkus produk yang lebih ramah lingkungan dan menyediakan galon air minum di stand masing- masing.

d) Melakukan promosi agar pengunjung membawa tumbler dan shopping bag masing-masing dalam rangka mengurangi penggunaan plastik.

\section{d. Site Plan}

Dalam tahapan membuat gambar tata letak (site plan) tim pengelolaan sampah memastikan setiap lokasi harus tersedia minimal dua tempat sampah yaitu sampah yang dapat di daur ulang dan sampah lainnya. Selain itu dipastikan jarak tempat sampah yang satu dengan yang lain berjarak minimal $20 \mathrm{~m}$, serta lokasi peletakan tempat sampah harus strategis dan mudah diliat, dan menugaskan beberapa petugas kebersihan yang telah diedukasi.

e. Promosi

Pihak Consina Outdoor Services Event melakukan promosi Program "Less Waste 
Event" dan memberi edukasi sebulan sebelum pelaksanaan acara tepatnya pada bulan Februari melalui media sosial Indonesia Outdoor Festival.

f. Perancanaan Sarana dan Prasarana

Langkah-langkah yang telah disiapkan didampingi dengan penyediaan sarana dan prasarana yang mendukung.

g. Perencanaan dan Pengelolaan Lokasi Wadah

Sangat diperlukan peletakan wadah di lokasi yang tepat, jumlah wadah yang cukup, serta pelabelan yang baik pada wadah sehingga tujuan program dapat tercapai.

\section{Metode Pelaksanaan Pada Saat Acara (Event)}

Berikut merupakan tahapan pelaksanaan Program "Less Waste Event" pada saat penyelenggaraan acara:

a. Kampanye Pengelolaan Sampah Pada Penyelenggaraan Acara

Kampanye pada saat penyelenggaraan acara dilakukan melalui pengeras suara dan poster.

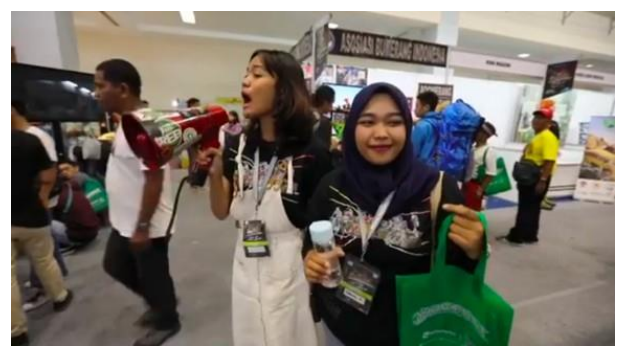

Gambar 3.

Kampanye Melalui Pengeras Suara Sumber: Dokumentasi Peneliti

b. Promosi

Promosi dilakukan dengan pemasangan tanda-tanda yang jelas, terlihat dan mudah dimengerti, serta letak dan jenis wadah tidak berubah-ubah.

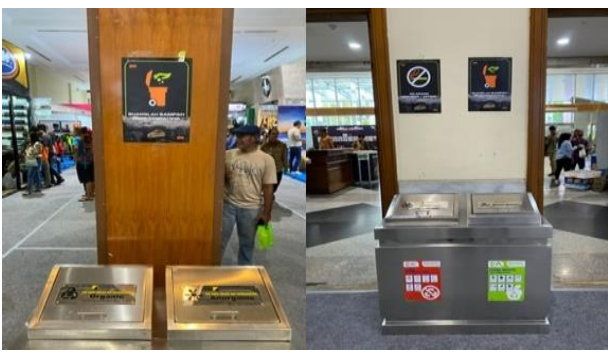

Gambar 4.

Promosi Program

Sumber: Dokumentasi Peneliti

c. Pengurangan Sampah

Pengurangan sampah merupakan komponen paling mendasar dari Program "Less Waste Event". Hal ini dilakukan dengan mengurangi penggunaan kemasan sekali pakai dan penyediaan galon air minum oleh para tenant, pembersihan area, dan penanganan sampah.

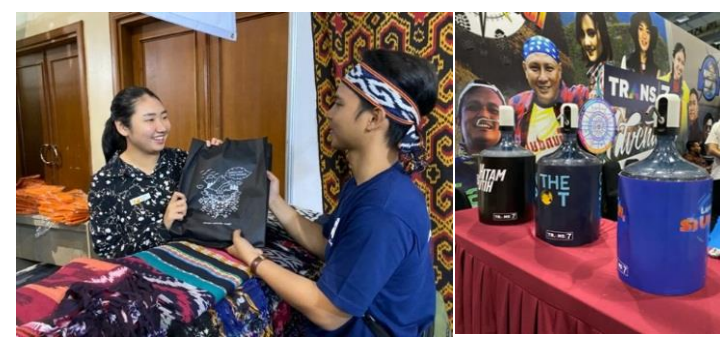

\section{Gambar 5.}

Pengurangan Sampah oleh Tenant Sumber: Dokumentasi Peneliti

\section{Metode Pelaksanaan Setelah Pelaksanaan Acara (Post-Event)}

Setelah pelaksanaan acara area harus terjaga sama seperti sebelum pelaksanaan dimulai atau bahkan lebih bersih. Hal yang dilakukan setelah pelaksanaan acara, yaitu:

a. Evaluasi

Setelah seluruh kegiatan dilaksanakan dilakukan evaluasi antara Consina Outdoor Services Event selaku pihak event organizer dengan Balai Sidang Jakarta Convention Center selaku pelaksana lapangan dari Program "Less Waste Event" pada pelaksanaan Indonesia Outdoor Festival 2020.

b. Promosi Pasca Acara

Kegiatan pengelolaan sampah pada penyelenggaraan acara dipromosikan 
kepada masyarakat sebagai bagian penting dari upaya penyadaran pengelolaan sampah yang baik kepada publik. Promosi pasca acara dilakukan melalui media sosial acara dengan menunggah foto pengelolaan sampah pada penyelenggaraan acara.

\section{Faktor-Faktor yang Mempengaruhi Kesuksesan Implementasi Program "Less Waste Event" pada Pelaksanaan Indonesia Outdoor Festival 2020}

Setelah peneliti melalukan wawancara kepada informan Bapak Muhammad Taufik selaku Assistant Director of Exhibition untuk menjawab beberapa pertanyaan terkait kriteria kesuksesan implementasi program. Semua data hasil penelitian ini diuraikan dalam beberapa fokus pertanyaan berdasarkan teori Islami sebagai berikut:

\section{Tahap Perencanaan Acara}

Agar implementasi suatu program dapat berjalan dengan sukses diperlukan perencanaan yang baik. Diperlukan komunikasi yang intens antara pihakpihak yang akan terlibat dalam pelaksanaan program "Less Waste Event" Indonesia Outdoor Festival 2020.

a) Proses perancanaan pelaksanaan Program “Less Waste Event" Indonesia Outdoor Festival 2020.

Perlu dilakukan kesepatan terlebih dahulu antara Consina Outdoor Services Event selaku event organizer untuk mengedukasi ke masyarakat luas. Manajemen Balai Sidang Jakarta Convention Center sebagai pihak venue untuk menjalankan menjalankan Program "Less Waste event.

b) Pemahaman pihak Balai Sidang Jakarta Convention Center selaku venue management akan rencana, tujuan, dan sasaran dari Program "Less Waste Event".

c) Persiapan Balai Sidang Jakarta Convention Center untuk menjalankan Program "Less Waste Event" pada pelaksanaan Indonesia Outdoor Festival 2020. Diantaranya : 1) Koordinasi teknis antara pihak event organizer dengan pihak operasional
Balai Sidang Jakarta Convention Center, dalam hal ini Departemen Housekeeping sebagai pelaksana lapangan, 2) Inventarisir permintaan event organizer untuk kelengkapan teknis pelaksanaan, 3) Brainstorming dengan pihak operasional perihal pelaksanaan program, dan 4) Memaksimalkan manajemen Program "Less Waste Event"."

\section{Tahap Pelaksanaan Acara}

Pada tahap pelaksanaan acara agar implementasi dari suatu program dapat berjalan dengan sukses maka seluruh pihak yang terlibat, utamanya unit pelaksana teknis/lapangan yang telah ditunjuk dapat menjalankan tanggung jawab yang telah diberikan. Dalam tahapan pelaksanaan acara dilakukan halhal sebagai berikut:

a) Unit pelaksana teknis dari Program "Less Waste Event" yang ditetapkan oleh Balai Sidang Jakarta Convention Center. unit pelaksana teknis yang ditunjuk oleh Balai Sidang Jakarta Convention Center selaku venue management adalah Departemen Housekeeping dan menunjuk Department Head Housekeeping untuk menjadi ketua pelaksana lapangan dari Program "Less Waste Event" pada pelaksanaan Indonesia Outdoor Festival 2020.

b) Kesiapan unit pelaksana teknis yang telah ditetapkan dalam menerima tanggung jawab pelaksanaan Program "Less Waste Event".

c) Koordinasi pelaksanaan Program "Less Waste Event". Berdasarkan hasil wawancara dan observasi dalam pelaksanaan acara mulai dari persiapan, pelaksanaan, hingga pembongkaran tidak ada masalah yang berarti. Selain itu pihak Consina Outdoor Services Event dan pihak Balai Sidang Jakarta Convention Center juga selalu berkoordinasi dengan baik

\section{Tahap Evaluasi Acara}

Tahapan ini dilakukan evaluasi terhadap implementasi program. Hal ini dapat 
dilakukan dengan melihat keberhasilan unit pelaksana teknis/lapangan dalam melaksanakan tanggung jawabnya dan melihat apakah program berjalan dengan sukses berdasarkan kriteria penilaian.

Dalam pelaksanaan event ini Pihak pelaksana dalam hal ini Departemen Housekeeping telah melaksanakan tugasnya dengan baik sesuai dengan ketentuan yang telah disepakati bersama antara event organizer dan pihak Balai Sidang Jakarta Convention Center sebelum program tersebut dilaksanakan.

Selain itu Untuk mengetahui keberhasilan pelaksanaan program perlu ditentukan kriteria penilaian. Dalam hal tersebut narasumber menyatakan bahwa: "Kami mengukur keberhasilanya dengan melihat kepuasan dari event organizer dalam pelaksanaan program ini, dan Balai Sidang Jakarta Convention Center telah mendukung dan menjalankan program dengan baik" (wawancara 13 April 2020).

\section{SIMPULAN}

1) Secara garis besar, implementasi Program "Less Waste Event" pada pelaksanaan Indonesia Outdoor Festival 2020 oleh Consina Outdoor Services Event di Balai Sidang Jakarta Convention Center telah berjalan sesuai dengan Pedoman Pengelolaan Sampah Pada Penyelenggaraan Acara yang dikeluarkan oleh Kementerian Lingkungan Hidup dan Kehutanan Republik Indonesia.

2) Implementasi Program "Less Waste Event" pada pelaksanaan Indonesia Outdoor Festival 2020 oleh Consina Outdoor Services Event di Balai Sidang Jakarta Convention Center telah dilaksanakan dengan sukses. Faktor-faktor yang mendukung keberhasilan event ini diantaranya :

a) Pada tahapan perencanaan acara telah dilakukan komunikasi yang baik antara Consina Outdoor Services Event sebagai penyelenggara acara dengan Balai Sidang Jakarta Convention
Center. Atas hal tersebut, pihak yang terlibat telah memahami Program "Less Waste Event", sehingga persiapan dapat dilakukan dengan baik.

b) Pada tahapan pelaksanaan acara pihak yang ditunjuk menjadi unit pelaksana teknis telah siap dan memahami tanggung jawabnya sehingga dapat

melaksanakan tugasnya dengan baik. Selain itu koordinasi juga berjalan dengan baik sehingga tidak ada permasalahan yang berarti.

\section{Saran}

1. Mewajibkan Seluruh Pelaksanaan Acara di Balai Sidang Jakarta Convention Center Melaksanakan Program "Less Waste Event". Sebagai upaya untuk mengaplikasikan prinsip ramah lingkungan dan sustainibility dalam pelaksanaan kegiatan MICE.

2. Membuat Kriteria Penilaian Keberhasilan yang Terperinci dalam Pelaksanaan Program “Less Waste Event”. Manfaat yang diperoleh dari hasil evaluasi yang diperoleh dapat terlihat di mana kekurangan implementasi program dan kedepannya dapat dilakukan perbaikan sehingga pelaksanaan event berikutnya dapat berjalan lebih baik lagi.

\section{DAFTAR PUSTAKA}

Arowoshegbe, A.O. and Uniamikogbo Emmanuel. (2016). Sustainibility and triple bottom line: an overview of two interrelated concepts. Igbinedion University Journal of Accounting, 2, 88-126.

Getz, Donald and Stephen J. Page. (2016). Progress and prospects for event tourism research. Tourism Management, 52, 593-631.

Kementerian Lingkungan Hidup dan Kehutanan Republik Indonesia. (2016). Pedoman Pengelolaan Sampah Pada Penyelenggaraan Acara. 
Maryono, H. (2010). Menakar Kebijakan RSBI: Analisis Kritis Studi Implementasi. Yogyakarta: Magnum Pustaka.

Mulyadi, D. (2015). Perilaku Organisasi dan Kepemimpinan Pelayanan. Bandung: Alfbeta.

Nawawi. (2003). Metode Penelitian Bidang Sosial. Yogyakarta: Gajah Mada University Press.

Noor, A. (2013). Manajemen Event. Bandung: Alfabeta.

Oxford Economics. (2018). Global Economic Significance of Business Events.

Sugiyono. (2012). Metode Penelitian Kuantitatif Kualitatif dan $R \& D$. Bandung: Alfabeta.

Tahir, A. (2014). Kebijakan Publik dan Transparansi Penyelenggaraan Pemerintah Daerah. Bandung: Alfabeta. 